\title{
University Students and Voting Behavior in General Elections: Perceptions on Malaysian Political Parties Leadership
}

\author{
Sivamurugan Pandian ${ }^{1}$ \\ ${ }^{1}$ School of Social Sciences, Universiti Sains Malaysia, Penang, Malaysia \\ Correspondence: Sivamurugan Pandian, School of Social Sciences, Universiti Sains Malaysia, 11800 USM, \\ Penang, Malaysia. E-mail: psiva@usm.my
}

Received: July 14, 2014 Accepted: July 23, 2014 Online Published: August 22, 2014

doi:10.5539/ass.v10n18p225 URL: http://dx.doi.org/10.5539/ass.v10n18p225

The author would like to thank Mohd. Shahril Badshah, School of Social Sciences, Universiti Sains Malaysia and Jonathan Francis Xavier, Asia Europe Institute, University of Malaya for their assistance in completing this research.

\begin{abstract}
Malaysia's 13th General Election held on 5 May 2013 was one of the most exciting General Elections in Malaysia's political history. The result showed that the ruling party Barisan Nasional (National Front) or BN and the opposition coalition Pakatan Rakyat (People's Alliance) or PR contested closely in the 222 Parliamentary seats. Although the results showed a rather status quo in favour of the ruling party, the opposition coalition managed to increase their seats to 89 compared to 82 from the 2008 12th General Election while the seats obtained by the ruling party reduced to 133 from 140 seats. National Youth Survey by the Asia Foundation indicated that the political thinking of the youths in Malaysia are not static but have changed accordingly. This new shift allows this paper to discuss the position of the youth in Malaysia with a reference to the selected university students on Malaysian political parties' leadership and which party will benefit from their role in Malaysian politics.
\end{abstract}

Keywords: Malaysia, youth, leadership, voting patterns, elections

\section{Introduction}

As it is now prevalent, the previously mellow emphasis placed on the more knowledgeable, nubile, energetic and charismatic young voter to produce change in the Malaysian democratic stagnancy is seeing a monumental expansion. Such a blatant and direct statement comes with proof of not only increased levels of political participation by the youth but also more open sharing of thoughts and ideas about the process itself. Allowing consideration on dimensions of age, political immaturity and volatility in decision making, many recently conducted research indicated that almost half of the first time voters in Malaysia were 'fence sitters' or eleventh hour decision maker. It is these undecided, issue based, rational thinking young voters who played a rather important role in the 2008 General Elections, causing disconnect with the ruling party's status quo styled campaign strategies (Pandian, 2010).

Illustrating this predicament is the 5\% vote disparity in 2013 between the Barisan Nasional (National Front), also known as BN (47\%) and Pakatan Rakyat (People Coalition), also called as PR (52\%) popular vote which signifies an understated shift away from the status quo although in the 'first past the goal post' system, what matters is the number of seats won and not the ballot paper received by parties involved. Adding to this scenario of youthful benevolence are statistics implicated by the Elections Commission where 450,000 Malaysian citizens turn 21 each year and that $70 \%$ of some 4.2 million unregistered voters are between the ages of 21 and 40 . In 2012, the EC noticed 2.4 million first time voters which constituted almost $30 \%$ of the entire voting population at the time (Nawab, 2013).

Stated above are, if not already acknowledged, consequential figures in highlighting the youth as game changers in the present Malaysian political arena. This article shall seek to explain the young voter's perceptions on the political party leadership and how this could very possibly shape their voting patterns and behaviours. The discussion is based on statistical figures, previous analyses and a strategically constructed questionnaire to gauge 
the depth of current opinion on the voting trend among youth in Malaysia. With the $13^{\text {th }}$ Malaysian General Elections which took place in May 2013 as a cornerstone indicator in this research, the young voter perceptions and the accompanying 'fence sitter' ideology will be scrutinized in detail, adding much needed intellectual flavor to a subject which has yet to unearth its truest potential.

\section{Previous Research and Background of Study}

Studies on voting behaviour and perceptions on party leadership such as this, though considerably important, are rarely prioritized when scrutinizing voting patterns and campaign outcomes. For example, research on this particular cohort that this article revolves around have yet to take popularity. Means (1991) in his study on the General Elections in 1969, 1974, 1978 and in 1982 deduced a certain correlation between the ethnicity factor and the strength of its influence on voters. He also discussed the General Elections in 1969 where open displays of racial and ethnic prejudice by the political parties had provoked strong racial sentiment and emotion among the general public, leading to the worst racial riots in the history of Malaysian Independence on the $13^{\text {th }}$ of May 1969.

In a similar case study, the 'Young Voter Support Trends' project Shamsul Amri (2013) found the younger voters to be more flexible and less interested in political happenings, rendering them more sensitive toward the issue of leadership. The younger voters were more inclined to root for Datuk Seri Mohd. Najib Tun Abd. Razak (Prime Minister and BN Chairman) than Dato' Seri Anwar Ibrahim (Opposition Leader and De Facto leader of People Justice Party). The transformation program undertaken at the time by the $\mathrm{BN}$ administration did seem to the voters as more meaningful than the regime change constantly promised by Anwar. Even so, a large number of voters were undecided at the time as most of them were non-Malays and lived in the cities. Thus, the urban constituencies depended much on these fence-sitters.

Behavioral studies among the younger voters, such as the ones mentioned above, had gained popularity among the Western scholars as well. Nicola Maggini (2009) had scrutinized voting patterns among the young voters in Italy. This study disproved the reliability and relevance of the Sociological Model in understanding such voting trends, as the results were more oriented toward factors such as individual choice, attitudes, values, interests and levels of participation in politics. Maggini had also discovered that the definitions for right and left wing politics had changed. The young cohort, especially the women voters, rarely attended church, whether they were young working adult women or students. These younger voters who were active in demonstrations, had a deep interest in politics, held post-materialist values and were neutral about issues such as homosexuality, had a strong tendency to vote for left wing parties as compared to the more conservative right wing political factions. Therefore, right wing and left wing politics were no longer focused on economic matters as they were before. The young voters who placed their support on left wing parties were at the time, in need of a more inclusive and universal worldview as compared to the limited, constrained and anti-universal right wing parties.

Wiese (2012) on a similar note had researched the voting behaviours of the university students in South Africa. His study had sought to illustrate the validity of the Western behavioral models in dissecting voting patterns among the students in South African universities. He had found the Sociological Model and the Michigan Model most feasible and relevant in such a setting. Being so, the Media Dominance Model had also illuminated its applicability as the students were seen to be alert and sensitive toward media reports. In sincere reciprocation, the media accepted their opinions and criticism of the government as well.

\section{The Students and Their Voting Patterns}

An elections analysis has never been complete without a focused observation on voting behaviour and patterns. Though in its early stages in Malaysia, previous studies on the subject were not entirely specific and had paid better attention in general to election results, party performance, campaign agenda and the issues involved (Faisal, 2002). There is still however an unequivocal lack in research that focuses on the voters themselves and the external factors that helped shape their corresponding voting behaviour, such as the issues that directly concerned them, voting factors, media influence, social media prevalence and the popularity element of the candidates involved. In attempting to complement past research and also produce a more complete and holistic study, this article shall also seek to rate the interests and concerns of the university students including their political preferences as they spearhead the nation's leadership transition and determine the future course of the Malaysian administration.

The 2013 General Elections saw both the BN and the PR politicians resort to extensive degrees of populist theatricals, which unsurprisingly sought to cater directly to the young voters. The BN handed out cash rebates for smartphone purchases worth under RM500.00 (US\$165.00) whereas PR candidates promised very hard to make redundant the National Higher Education Fund Corporation (PTPTN) student loan system, lower car prices, 
introduce better minimum wage laws and even curb rapidly rising property prices. A very noticeable campaigning strategy which employed the application of general needs and catered to specific social environments replaced the older version of communal campaigning involving racial inequality. A study conducted by the Asia Foundation (2012) implicated how the youth are no longer predisposed in relating politics to neither religious nor racial propensity. A rising category of independent, intellectual, open minded, selfless and politically inclined young voters or $71 \%$ of the sample selected were reported to be in want of a party that was more multiracial and inclusive for all Malaysians regardless of race or religion.

This group of young student voters was predominantly more concerned about the general issues which involved the political parties at both the national and local levels, instead of traditional ethnic comparatives. The PR had taken advantage of such enthusiasm at first by expounding active concern about rampant corruption, government spending, good governance, rising claims of cronyism, the usage of 'Allah' and even PKR Vice President Tian Chua's ill-intentioned statement on the Lahad Datu incident (theposto.com, 2012). Its inclusive and practical approach which catered to a better united Malaysian population not only ensured the young voters a voice in the political arena but also faded the communal differentials in preference for a common agenda of issues. Even though communal based policies had sought to bludgeon BN credibility by incurring fear among the ethnic Malays of their diminishing rights in a rapidly developing multiethnic populace, overall $60 \%$ of the cohort thought that BN had fared rather well, needing only some targeted improvements wherever necessary in its bid for good governance and clearer transparency.

In similar perspective, democracy and the levels of political participation allowed or induced by any one state administration depends also on the level of political articulacy the people display and are capable of. The sample in this study consists of a fairly articulate cohort, which understands not only the current goings on in the national political environment but also are adept in making pragmatic predictions based on the information collected. Thus the young voters are fully capable though not entirely experienced in practicing their democratic rights and principles. As the results of this study will show, the 'fence sitters' are also to be measured by the varying levels of political participation and not just their political articulacy (Stokes, Susan, Dunning, Thad, Nazareno, Marcelo, Brusco, \& Valeria, 2013).

By characterizing political participation into form, frequency and quality, the extent of an individual's political motivation is observable. The difference between conventional forms of participation which include involvement in only voting and campaigning and the non-conventional forms which include active involvement in protests, demonstrations, revolutions and flagrant displays of political hostility may explain to a certain degree a variety of contributing factors and their inherent measure of political activity. Also the repetitive aspect of a political act is just as important in determining the perceptions involved as is the meaningfulness of an individual's commitment in or contribution to a political process, where his or her understanding and knowledge on political systems and the subsequent processes that ensue would become the main factors in determining the quality of political involvement. In recent times, the accessibility factor of the media and alternative media sources have outstandingly contributed to increased student political participation though as mentioned above, the depth or quality of such activity remains unknown (Prior, 2007).

University students may also be categorized into varying levels of political participation in order to gauge their perceptions and voting behaviour. This is done according to Mohd Faisal (2002) with six different levels of involvement ranging from the inactive (least active), the voting experts, the parochial participant, the societal activist, the campaigning groups and finally the full activist (most active). A strong urge for politicking, compounded by an extroverted nature may also be conducive in shaping an individual's sociability and perspective on values such as justice and fairness, inducing a sense of responsibility to become politically involved in the process. Institutionalization and social environments play important roles in this study on university students' perceptions and voting patterns as the selected cohort's family background, hometown and social class are all very influential factors in shaping their perspective. It may be safe to say that no single factor outshines any other in this discussion on student perceptions on party leadership and their corresponding voting patterns.

\section{Research Findings and Results}

This study focused to the perception and voting behaviour of students from a few Malaysian local universities is integral as a form of guidance for political parties in preparing for future elections in the country. Among the various Behavioral Models used to assess the opinions obtained were the Sociological Model, the Michigan Model, the Party Identification Model, the Ideology/Media Dominance Model and the Rational Choice Model which were of great assistance in measuring the level of institutionalization against freedom of choice parallel 
with the issues affecting them. At times, interplay of two or more models was used to accord for the lack of proper measurement systems when it came to identifying the level of meaningful political participation.

The primary data source consisted 615 respondents from Universiti Putra Malaysia (UPM: 105), Universiti Kebangsaan Malaysia (UKM: 125), Universiti Sains Malaysia (USM: 148), Universiti Malaysia Sabah (UMS: 102) and Universiti Malaysia Sarawak (UNIMAS: 135), divided into proportions of 144 male, 469 female and 2 respondents of unknown gender (unstated).

From the 615 respondents, 354 respondents were below the age of 20, 240 were between ages 21 and 24,15 were between ages 25 and 30, 3 were between ages 31 and 35 and 1 was in the 41-45 age category. All in all, it may be observed that the distribution of voters who were not yet eligible to vote (first time voter for the $14^{\text {th }}$ General Elections) due to the age factor was prominent at $57.7 \%$. The ethnic distribution saw 416 Malays, 59 Chinese, 37 Indian, 92 others and 11 unstated respondents. The observable majority in this study almost mirrored the national distribution with $67.6 \%$ while the second largest ethnic group was the 'Others' with $15 \%$. The breakdown according to state of origin was that from a total of 615 respondents, $15.3 \%$ were from Sabah, $12 \%$ from Johor and $11.5 \%$ were from Sarawak. Perlis saw the least amount of respondents with only $1.1 \%$. Geographically, $73.2 \%$ were from West Malaysia (Peninsula) whereas $26.8 \%$ were from the East (Sabah \& Sarawak). In the Peninsula itself, the breakdown was $71.8 \%$ from the West Coast and the remaining $28.2 \%$ were from the East Coast.

Table 1. Distribution of student perception according to ethnicity

\begin{tabular}{|c|c|c|c|c|c|c|c|c|c|c|c|c|}
\hline & \multicolumn{12}{|l|}{$\%$} \\
\hline & \multicolumn{3}{|c|}{ Malay } & \multicolumn{3}{|c|}{ Chinese } & \multicolumn{2}{|c|}{ Indian } & \multicolumn{4}{|c|}{ Others } \\
\hline & $\mathbf{A}$ & B & C & $\mathbf{A}$ & B & C & $\mathbf{A}$ & B & C & $\mathbf{A}$ & B & C \\
\hline $\begin{array}{l}\text { Realization of involvement of other } \\
\text { parties besides BN and PR }\end{array}$ & 24.5 & 30.7 & 12.2 & 2.6 & 4.7 & 2.3 & 2.3 & 2.6 & 1.1 & 6.8 & 4.4 & 3.6 \\
\hline $\begin{array}{l}\text { Support of these other parties in } \\
\text { pursuit of fairness and justice }\end{array}$ & 36.3 & 5.9 & 19.1 & 5.2 & 1.6 & 2.8 & 3.9 & 0.8 & 1.3 & 7.8 & 2.8 & 7.2 \\
\hline $\begin{array}{l}\text { Support of the 'Change Now' } \\
\text { manifesto by the opposition parties }\end{array}$ & 13.8 & 27.3 & 26.1 & 4.2 & 1.3 & 4.1 & 2.6 & 1.5 & 2.0 & 4.6 & 3.1 & 7.2 \\
\hline $\begin{array}{l}\text { Support of a fair set of traditions in } \\
\text { the transition from status quo }\end{array}$ & 27.5 & 19.3 & 20.1 & 6.2 & 1.0 & 3.1 & 3.6 & 1.1 & 1.0 & 5.9 & 2.8 & 6.0 \\
\hline $\begin{array}{l}\text { Support of the opposition parties due } \\
\text { to issues of equality for all }\end{array}$ & 34.5 & 14.8 & 21.0 & 4.1 & 1.3 & 4.2 & 3.4 & 1.0 & 1.6 & 7.2 & 2.4 & 5.2 \\
\hline $\begin{array}{l}\text { To support the BN due to Datuk Seri } \\
\text { Mohd. Najib Tun Abd. Razak's } \\
\text { popularity }\end{array}$ & 14.3 & 27.5 & 25.7 & 2.8 & 3.9 & 2.8 & 1.8 & 1.9 & 2.1 & 2.1 & 6.7 & 5.8 \\
\hline $\begin{array}{l}\text { To support the PR due to Dato' Seri } \\
\text { Anwar Ibrahim's popularity }\end{array}$ & 4.2 & 52.7 & 10.6 & 0.2 & 7.5 & 1.8 & 0.2 & 4.5 & 1.3 & 0.8 & 11.0 & 2.9 \\
\hline $\begin{array}{l}\text { Support of the 1Malaysia concept by } \\
\text { Datuk Seri Mohd. Najib Tun Abd. } \\
\text { Razak }\end{array}$ & 11.2 & 43.7 & 12.7 & 2.4 & 4.4 & 2.8 & 1.6 & 3.2 & 1.1 & 3.6 & 8.1 & 2.9 \\
\hline $\begin{array}{l}\text { Agree that Dato' Seri Anwar Ibrahim } \\
\text { will stop at nothing to become the } \\
\text { Prime Minister }\end{array}$ & 32.2 & 20.6 & 14.8 & 3.9 & 2.9 & 2.8 & 3.1 & 1.3 & 1.6 & 7.6 & 3.6 & 3.6 \\
\hline $\begin{array}{l}\text { Support of the New Economic Model } \\
\text { by Datuk Seri Mohd. Najib Tun Abd. } \\
\text { Razak }\end{array}$ & 34.3 & 11.7 & 21.6 & 3.9 & 1.5 & 4.2 & 2.8 & 1.5 & 1.8 & 8.6 & 1.8 & 4.4 \\
\hline $\begin{array}{l}\text { Support Dato' Seri Anwar Ibrahim in } \\
\text { taking over the government as PM }\end{array}$ & 14.1 & 32.2 & 21.3 & 2.1 & 2.9 & 4.4 & 1.6 & 1.3 & 3.1 & 3.1 & 4.9 & 6.8 \\
\hline $\begin{array}{l}\text { Support of the Government } \\
\text { Transformation Plan (GTP) and the } \\
\text { Economic Transformation Plan (ETP) }\end{array}$ & 25.8 & 16.9 & 24.9 & 2.1 & 2.6 & 4.9 & 2.4 & 1.1 & 2.4 & 6.2 & 1.9 & 6.7 \\
\hline
\end{tabular}

*A: Yes; B: No; C: Unsure. 
A total of 83 respondents had marked 'Yes' to having voted before whereas 531 respondents or $86.3 \%$ had marked 'No' further accentuating the first time voter phenomena mentioned above. In having registered as a voter, a total of 136 respondents or $22.1 \%$ had marked 'Yes' whereas 476 respondents or $77.4 \%$ had marked 'No.' This study had taken into account some fairly significant aspects in not only structuring the questionnaire but in also the discretionary analysis that followed after. Among these aspects taken into consideration were the backgrounds of the respondents (faculty, gender, and age, voting status, voting location, their perception on both their area representative and Member of Parliament), the implementation of government policies, political party leadership, sensitivity toward the issues that may affect the voting process and characteristics of an ideal leader. Though these aspects appear discrete, they are very much interrelated in articulating the young voter perception.

Table 1 shows the responses given with respect to party leadership issues according to ethnicity. Further analyses replacing the ethnicity factor with gender and location in the state will follow. However, Table 1 is to be used as the main reference to responses given by the students in understanding the ethnic relations in the current national political arena. As will further discussion dictate the lack of communal propensity among the university students, the distribution in Table 1 highlights such an attribute in numerical detail. Overall, it is apparent that the ethnic Malay students were positive about Najib's efforts with the Government Transformation Plan (GTP), the Economic Transformation Plan (ETP) and the New Economic Model. They do however; appear less confident with the leadership approach of Anwar.

The ethnic Chinese students on the other hand were not direly supportive of the Najib administration but were not entirely enthusiastic with Anwar's leadership either. This is observable from Table 1 where only $0.2 \%$ of the ethnic Chinese students marked 'Yes' in support of Anwar's popularity while 7.5\% marked 'No' and another $1.8 \%$ were unsure. Characteristic of decisions related to stability the ethnic Chinese students were rather consistent in their responses. The ethnic Indian students were generally positive in their responses toward the Najib administration though their first few responses reflected support for change from the status quo of the BN administration. Students from the 'Others' category however were critical toward Najib's style of leadership and questioned the credibility of the 1Malaysia concept as according to them, it is still failing to be convincing in its promotion of ethnic and cultural diversity.

When analyzed according to gender distributions, both the male and female respondents displayed high levels of positive responses in support for parties other than the BN or PR, external parties which fought for better fairness and justice, traditional values of fairness in changing the current status quo system, support for the opposition parties which prioritized freedom, justice and equality for all and were only lukewarm in embracing Najib's political popularity. However, the patterns were very consistent when the respondents were questioned on Anwar Ibrahim's popularity as both the male and female respondents were stoically negative in their responses. Respondents were also mildly disbelieving of the 1Malaysia concept as they had maybe yet to comprehend a clearer definition of the $\mathrm{BN}$ version when placed side by side with the extremely secular version expounded by PR. Both the male and female respondents had agreed to Anwar's unstoppable determination in winning the top post and supported wholly Najib's New Economic Model. They were also supportive of the BN administration's GTP and ETP plans for national development.

Generally, the female university students were more positive about and supportive of Najib's leadership style as compared to the male students, though the female students presented a higher than usual percentage of undecided 'fence sitters.' Even so, both sides did not display sufficient confidence in Anwar's bid to run the country in the near future. Geographically, results obtained almost mirrored the ethnic composition percentages as illustrated in Table 1 above. Though respondents from West Malaysia (the Peninsula) were rather accepting of the BN administration, respondents who originated from Sabah, Sarawak and Labuan were very skeptical and negative especially when it came to issues of diversity and equal opportunities. The East Malaysian respondents not only lacked confidence in Najib but also Anwar and openly supported the notion of political change in the nation's administration. They had also strongly shown dislike with the 1Malaysia concept but overtly supported economic based initiatives advocated by the $\mathrm{BN}$ administration.

In short, there exists a certain degree of coherence between the students from the Peninsula and students from the Sabah, Sarawak and Labuan states in terms of party affiliation. Though the respondents from the East were more critical toward BN in terms of freedom, equality and acceptance of diversity, both sides were agreeable with and supportive of Najib's initiatives when it came to national economic development.

\section{Conclusion}

The university students today are less reserved in their opinions about the government and its opposition. They feel a personalized responsibility in expressing how they feel toward the institutionalization of the state and its 
systems. Such an increased and heightened level of political participation has ensured the loss in popularity of certain government policies and agenda, especially the ones which concern the welfare of the general Malaysian population. Also, an exceptional finding is that the intellectual and creative thinking students no longer place copious amounts of trust in the reliability of information transmitted by the mainstream media. The elaborations and explanations offered by the government on citizen welfare and development policies seem to be no longer well received. The rapidly emerging alternative media source with its tempting allocation in freedom of expression via the social media scene is seeing expanded usage by the students, which is something BN should be attempting to match up in. BN strategies must be able to keep up with fast developing technology.

Interracial unity is also a subject that must be addressed with better efficiency, intelligence and understanding by BN politicians. There should be better campaigns and elaborate infrastructure in deepening general understanding on sensitive topics related to ethnic and racial proportions such as affirmative action (NEP) and the social contracts that are stated in the Constitution. From this study, even the robust 1Malaysia concept might need better enlightenment so as to serve its functionality better. The students have also begun to express their dissatisfaction with BN's efforts in combating corruption and have called for better transparency in the matter. BN for its own benefit could use such feedback as betterment factors in its quest to tighten the distance between the party and the university students.

The students are, as mentioned in this study, attracted by and pay close attention to exemplary leadership skills. To them, an ideal leader is honest, ethical, knowledgeable and authoritative, characteristics that need only be adjusted with the BN leaders so as to win more votes and restore wholesome confidence to the party itself. Finally, though Najib's leadership approach may not have won hands down when compared with Anwar's strategic management, however the students were still much more in favour of the BN politician at the moment. His economic agenda and national development plans are better sounding and more robust in nature when compared with the opposition party's quest for human rights and equal treatment. Such perceptions are better protected or improved in preparation for the next general elections as 'fence-sitters' among the youth are always indecisive and changes accordingly.

\section{Acknowledgments}

The author would like to thank Universiti Sains Malaysia for the Short Term Grant [304/PSOSIAL/6312086] which supported this research.

\section{References}

Baharuddin, S. A., \& Noor, M. M. (Eds.). (2013). PRU-13 Siapa Pilihan Pengundi? Bangi: UKM.

Bartels, L. M. (2008). The Study of Electoral Behavior. Retrieved from http://www.princeton.edu/ bartels/ electoralbehavior.pdf

Haron, S., \& Musib, Z. (Eds.). (2012). Pemasaran Politik Di Malaysia. Kuala Lumpur: DBP.

Hazis, M. F. S. A., Mersat, N. I., \& Sarok, A. (2002). Tingkahlaku Pengundian Dalam Pilihan Raya Parlimen Sarawak, Kota Samarahan. Malaysia: Universiti Malaysia Sarawak.

Higher Education Research Institute, University of California, Los Angeles. (2004). Trends In Political Attitudes And Voting Behavior Among College Freshmen And Early Career Early College Graduates: What Issues Could Drive This Election? Retrieved from http://www.heri.ucla.edu/pdfs/full_political_attitudes.pdf

Maggini, N. (2009). Voting Behaviour of the Young Generations. Presented at the 5th ECPR General Conference 2009, Potsdam (2009). Retrieved from http://povb-ecpr.org/node/67

Means, G. (1991). Malaysian Politics: The Second Generation. London: Oxford University Press.

Osman, M. N. M. (2013). The Youth Vote in GE 2013: Kingmakers in the Making? Retrieved from http://www.rsis.edu.sg/publications/Perspective/RSIS0652013.pdf

Pandian, S. (2010). 2006 Sarawak State Election: Issue and Electoral Results. Canadian Social Science, 15(5). Canada: CSCanada.

Pandian, S., \& Daud, N. M. (2011). Voting Behavior In The Permatang Pauh Parliament Constituency: Post 2008 Malaysia's General Elections. Germany: LAP Lambert Academic Publishing.

Prior, M. (2007). Post-Broadcast Democracy: How Media Choice Increases Inequality in Political Involvement and Polarizes Elections. United Kingdom: Cambridge Press. http://dx.doi.org/10.1017/CBO978113987 8425 
Spannnring, R., Ogris, G., \& Gaiser, W. (Eds.). (2008). Youth and Political Participation in Europe: Result of the Comparative Study EUYOPART. USA: Barbara Budrich Publishers.

Stokes, S., Dunning, T., Nazareno, M., \& Brusco, V. (2013). Brokers, Voters, and Clientelism: The Puzzle of Distributive Politics. United Kingdom: Cambridge Press. http://dx.doi.org/10.1017/CBO9781107324909

Wiese, C. E. (2012). An Exploration of the Voting Behaviour of South African University Youth: A Study of a Select Group of University Students (Dissertation M.A.). Retrieved from http:/upetd.up.ac.za/thesis/ available/etd-12122011-104324/http://asiafoundation.org/news/2012/12/the-asia-foundation-launches-the-y outh-factor-2012-survey-of-malaysian-youth-opinion/http://www.theposto.com/2013/?p=1144

\section{Copyrights}

Copyright for this article is retained by the author(s), with first publication rights granted to the journal.

This is an open-access article distributed under the terms and conditions of the Creative Commons Attribution license (http://creativecommons.org/licenses/by/3.0/). 